\title{
Comparison of the Superoxide Dismutases of Branhamella catarrhalis, Neisseria ovis, and Neisseria caviae
}

\author{
E. PININA NORROD, LYNNE BARTENSTEIN, AND STEPHEN A. MORSE \\ Department of Microbiology and Immunology, University of Oregon Health Sciences Center, \\ Portland, Oregon 97201
}

\begin{abstract}
We characterized the superoxide dismutases of Neisseria ovis, Neisseria caviae, and Branhamella catarrhalis after electrophoresis. Comparisons of the metal contents (as determined by sensitivity to hydrogen peroxide) and the relative mobilities of the dismutases showed that the dismutases of all six isolates of $B$. catarrhalis were identical to each other and to the dismutase of $N$. ovis strain T2B. The dismutase of $N$. caviae was similar to the dismutases of the $B$. catarrhalis strains in that it also contained manganese. However, the dismutase of $N$. ovis strain NRL 30014 was more similar to the dismutases of 17 other Neisseria strains previously tested in that it appeared to contain iron instead of manganese.
\end{abstract}

The classification of Neisseria ovis and Neisseria caviae is uncertain. In Bergey's Manual of Determinative Bacteriology, 8th ed., these bacteria are listed as species incertae sedis (25). Proposals to place N. ovis and N. caviae in the same genus as Branhamella catarrhalis have been based upon several characteristics of $N$. ovis and $N$. caviae which are shared with $B$. catarrhalis but not with other species of Neisseria. These characteristics include the guanineplus-cytosine content of the deoxyribonucleic acid (2), electrophoretograms of esterases (10), and gas chromatograms of cellular carbohydrates $(3,13)$, cellular fatty acids $(3,12,13,16)$, and metabolic products (20). Recently, we reported that $N$. ovis was the only 1 of 17 Neisseria strains tested which had a manganese-containing superoxide dismutase (22). This led us to compare the superoxide dismutases of $N$. ovis, $N$. caviae, and B. catarrhalis.

\section{MATERIALS AND METHODS}

Bacterial strains and culture conditions. The strains used in this study are listed in Table 1. All strains were grown in a defined liquid medium (21), as described previously (22).

Assays for superoxide dismutases. Cell-free extracts were prepared as described previously (22). Spectrophotometric assays for superoxide dismutases were based on the inhibition of cytochrome $c$ reduction (18). After electrophoresis (6) on polyacrylamide gels containing $10 \%$ acrylamide and $0.03 \% N, N^{\prime}$-methylene bisacrylamide, the gels were stained for superoxide dismutase activity (1). Before staining, duplicate gels were treated with $5 \mathrm{mM}$ hydrogen peroxide (5) or buffer; iron-containing superoxide dismutases were inhibited markedly, whereas manganese-containing superoxide dismutases were not affected.

Test for DNase activity. Bacteria were grown on dioxyribonuclease (DNase) test agar (Difco Laboratories, Detroit, Mich.) at $37^{\circ} \mathrm{C}$ in $4 \% \mathrm{CO}_{2}$ for $24 \mathrm{~h}$. Deoxyribonucleic acid hydrolysis was detected by adding $0.1 \%$ toluidine blue in deionized water (26).

\section{RESULTS}

Table 2 shows that the superoxide dismutases of $N$. ovis T2B (the strain of $N$. ovis previously tested [22]), six isolates of $B$. catarrhalis (including ATCC 25238), and $N$. caviae ATCC 14659 shared the following characteristics: (i) superoxide dismutase activity in gels after electrophoresis was confined to a single band; (ii) the relative mobilities of the enzymes from all isolates of $B$. catarrhalis and $N$. ovis T2B were identical, whereas the relative mobility of the $N$. caviae enzyme was similar, although slightly less; and (iii) superoxide dismutase activity was not inhibited by dilute hydrogen peroxide. This lack of inhibition strongly suggested that these enzymes contain manganese (5), whereas the superoxide dismutases of all other Neisseria strains that have been tested contain iron (22).

The superoxide dismutase of $N$. ovis NCTC 11227 seemed more similar to the superoxide dismutases of other Neisseria species than to the dismutases of the other strains of $N$. ovis, $N$. caviae, and B. catarrhalis in that it was inhibited by hydrogen perioxide. The difference between the superoxide dismutases of the two strains of $N$. ovis was surprising and raised the question of whether $N$. ovis T2B might share other characteristics with $B$. catarrhalis. The DNase activity of $B$. catarrhalis may be helpful in distinguishing $B$. catarrhalis from other Neisseria strains $(19,26)$. We tested all of the bacteria listed in Table 2 for DNase activity and 
TABLE 1. Production of DNase and beta-lactamase by $B$. catarrhalis and Neisseria strains

\begin{tabular}{|c|c|c|c|c|c|}
\hline Species & Strain & $\begin{array}{l}\text { Production } \\
\text { of DNase }\end{array}$ & $\begin{array}{c}\text { Production } \\
\text { of beta-lacta- } \\
\text { mase }^{a}\end{array}$ & Source of $\operatorname{strain}^{h}$ & Reference \\
\hline \multirow[t]{18}{*}{ B. catarrhalis } & W-786 & + & + & Doern and Morse & 7 \\
\hline & ATCC 8176 & + & - & ATCC & \\
\hline & 324 & + & + & Doern and Morse & 7 \\
\hline & 634 & + & + & Doern and Morse & 7 \\
\hline & 318 & + & + & Doern and Morse & 7 \\
\hline & NRL $30018(\text { ATCC } 25238)^{c}$ & + & - & NRL (ATCC) & \\
\hline & 6D2 & + & + & UOHSC & \\
\hline & $7 \mathrm{C} 10$ & + & + & UOHSC & \\
\hline & $7 \mathrm{H} 9$ & + & - & UOHSC & \\
\hline & 1165 & + & - & UOHSC & \\
\hline & 4120 & + & + & Doern and Morse & 7 \\
\hline & NRL A1262 & + & + & NRL & \\
\hline & NRL A1246 & + & + & NRL & \\
\hline & NRL A1649 & + & + & NRL & \\
\hline & NRL A 1650 & + & + & NRL & \\
\hline & NRL A1656 & + & + & NRL & \\
\hline & 1526 & + & - & OSPHL & \\
\hline & 2233 & + & + & Doern and Morse & 7 \\
\hline \multirow[t]{2}{*}{ N. ovis } & $\mathrm{T} 2 \mathrm{~B}$ & - & - & $\mathrm{CDC}$ & \\
\hline & 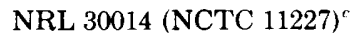 & - & - & NRL (NCTC) & \\
\hline N. caviae & NRL $30002{\text { (ATCC } 14659)^{c}}^{c}$ & - & - & NRL (ATCC) & \\
\hline \multirow[t]{2}{*}{ N. perflava } & ATCC $10555^{\circ}$ & - & - & ATCC & \\
\hline & 4326 & - & - & WRAIR & \\
\hline N. subflava & $\mathrm{B} 886$ & - & - & $\mathrm{CDC}$ & \\
\hline N. flava & 4322 & - & - & WRAIR & \\
\hline N. flavescens & ATCC $13120^{\circ}$ & - & - & ATCC & \\
\hline N. mucosa & A7895 & - & - & $\mathrm{CDC}$ & \\
\hline
\end{tabular}

${ }^{a}$ Beta-lactamase activity was detected with the chromogenic substrate Nitrocefin (Galaxo).

${ }^{b}$ ATCC, American Type Culture Collection, Rockville, Md.; NCTC, National Collection of Type Cultures, London, England; NRL, Neisseria Reference Laboratory, U.S. Public Health Service Hospital, Seattle, Wash.; UOHSC, Clinical Pathology Laboratory, University of Oregon Health Sciences Center, Portland; OSPHL, Oregon State Public Health Laboratory, Portland; CDC, Centers for Disease Control, Atlanta, Ga.; WRAIR, Walter Reed Army Hospital Institute for Research, Bethesda, Md.

c Type strain (27).

TABLE 2. Comparison of superoxide dismutases of B. catarrhalis and Neisseria strains

\begin{tabular}{|c|c|c|c|c|c|}
\hline \multirow[b]{2}{*}{ Organism } & \multirow[b]{2}{*}{ Strain } & \multirow{2}{*}{$\begin{array}{l}\text { Superoxide dis- } \\
\text { mutase activity } \\
\text { (U/mg of pro- } \\
\text { tein) }\end{array}$} & \multirow{2}{*}{$\begin{array}{l}\text { No. of bands } \\
\text { positive for dis- } \\
\text { mutase activity } \\
\text { per strain }\end{array}$} & \multicolumn{2}{|c|}{ Relative mobility } \\
\hline & & & & $\begin{array}{c}\text { Bands with } \\
\text { dismutase } \\
\text { activity }\end{array}$ & $\begin{array}{c}\text { Bands in- } \\
\text { hibited by } \\
\mathrm{H}_{2} \mathrm{O}_{2}{ }^{a}\end{array}$ \\
\hline B. catarrhalis & W-786 & 40.9 & 1 & 0.66 & \\
\hline B. catarrhalis & ATCC 8176 & 19.1 & 1 & 0.66 & \\
\hline B. catarrhalis & 324 & 10.8 & 1 & 0.66 & \\
\hline B. catarrhalis & 634 & 21.8 & 1 & 0.66 & \\
\hline B. catarrhalis & 318 & 7.4 & 1 & 0.66 & \\
\hline B. catarrhalis & ATCC 25238 & 18.1 & 1 & 0.66 & \\
\hline$N$. ovis & T2B & 32.0 & 1 & 0.66 & \\
\hline N. ovis & NCTC 11227 & 6.8 & 1 & 0.55 & 0.55 \\
\hline N. caviae & ATCC 14659 & 4.9 & 1 & 0.61 & \\
\hline N. gonorrhoeae & Seven strains ${ }^{b}$ & $0-1.1$ & $0-1$ & $0.38-0.45$ & All \\
\hline N. meningitidis & Three strains $^{b}$ & $6.3-14.4$ & 1 & 0.42 & All \\
\hline Nonpathogenic Neisseria & Six strains ${ }^{b}$ & $1.9-22.3$ & $1-4$ & $0.45-0.59$ & All \\
\hline
\end{tabular}

${ }^{a}$ Manganese-containing superoxide dismutases are not inhibited by $5 \mathrm{mM} \mathrm{H}{ }_{2} \mathrm{O}_{2}$, whereas iron-containing dismutases are inhibited (5).

${ }^{b}$ See reference 22 . 
found that all isolates of $B$. catarrhalis were positive, whereas $N$. caviae and both strains of $N$. ovis were negative. For further evidence that DNase activity distinguished $B$. catarrhalis from other Neisseria strains, we tested the Neisseria strains listed in Table 1 and found that all were negative for DNase activity.

\section{DISCUSSION}

Superoxide dismutase, which catalyzes the dismutation of the superoxide radical to hydrogen peroxide and oxygen, is probably important in preventing oxygen toxicity $(11,18)$. Whereas eucaryotic dismutases contain either copper and zinc or manganese $(9,17,18,28)$, all bacterial dismutases thus far discovered contain either manganese or iron $(4,5,23)$, with the exception of a copper-containing dismutase from a fish symbiont (24). Some bacteria, such as Escherichia coli, possess both iron-containing superoxide dismutases $(4,29)$ and manganese-containing superoxide dismutases $(4,14)$, whereas other bacteria possess one or the other $(5,23)$. Identification of the metal in a superoxide dismutase is possible without purification of the enzyme. After electrophoresis, iron-containing enzymes are sensitive to hydrogen peroxide, whereas manganese-containing dismutases are not (5). The reliability of this method has been shown by reconstitution of the apoenzymes with the appropriate metals (15).

Our results show that the superoxide dismutases of the six isolates of $B$. catarrhalis examined in detail are identical in that upon electrophoresis the relative mobilities are the same and the single dismutase of each isolate contains manganese. The various sources of these strains and the occurrence of $\beta$-lactamase activity which is not due to the presence of a plasmid (8) indicate that the identical dismutases of the $B$. catarrhalis isolates are not the result of dissemination of a single clone. Since the superoxide dismutases of $N$. ovis T2B and $N$. caviae ATCC 14659 appeared to be similar to the superoxide dismutase of $B$. catarrhalis, we initially thought that this provided additional evidence that $N$. ovis and $N$. caviae belong in the genus Branhamella, especially since, of the 17 other Neisseria strains previously examined, only $N$. ovis T2B had a manganese-containing superoxide dismutase. These bacteria are related on the basis of other characteristics. The detection of an apparent iron-containing dismutase in $N$. ovis NCTC 11227 may invalidate classification on the basis of the metal content of the superoxide dismutase. However, the identity of $N$. ovis NCTC 11227 should be established before final conclusions are reached. Even though the metal contents of the superoxide dismutases in the strains currently identified as $N$. ovis may vary, our results show that some isolates (such as $B$. catarrhalis isolates) characterized on the basis of other criteria are strikingly similar in DNase activity, electrophoretic characteristics of their superoxide dismutases, and metal contents of their superoxide dismutases.

\section{REPRINT REQUESTS}

Address reprint requests to: Dr. Stephen A. Morse, Department of Microbiology and Immunology, University of Oregon Health Sciences Center, 3181 SW Sam Jackson Park Road, Portland, OR 97201.

\section{LITERATURE CITED}

1. Beauchamp, C., and I. Fridovich. 1971. Superoxide dismutase: improved assays and an assay applicable to acrylamide gels. Anal. Biochem. 44:276-287.

2. Bovre, K., M. Fiandt, and W. Szybalski. 1967. DNA base composition of Neisseria, Moraxella and Acinetobacter, as determined by measurements of buoyant density of $\mathrm{CsCl}$ gradients. Can. J. Microbiol. 15:335338.

3. Bøvre, K., R. Hytta, E. Jantzen, and I. O. Frøholm. 1972. Gas chromatography of bacterial whole cell methanolysates. Acta Pathol. Microbiol. Scand. Sect. B 80: 683-689.

4. Britton, L., and I. Fridovich. 1977. Intracellular localization of the superoxide dismutases of Escherichia coli: a re-evaluation. J. Bacteriol. 131:815-820.

5. Britton, L., D. P. Malinowski, and I. Fridovich. 1978. Superoxide dismutase and oxygen metabolism in Streptococcus faecalis and comparisons with other organisms. J. Bacteriol. 134:229-236.

6. Davis, B. J. 1964. Disc electrophoresis. II. Method and application to human serum proteins. Ann. N.Y. Acad. Sci. 121:404-427.

7. Doern, G. V., and S. A. Morse. 1980. Branhamella (Neisseria) catarrhalis: criteria for laboratory identification. J. Clin. Micribiol. 11:193-195.

8. Doern, G. V., K. B. Siebers, L. M. Hallick, and S. A. Morse. 1980. Antibiotic susceptibility of beta-lactamase-producing strains of Branhamella (Neisseria) ca tarrhalis. Antimicrob. Agents Chemother. 17:24-29.

9. Forman, H. J., and I. Fridovich. 1973. On the stability of bovine superoxide dismutase. J. Biol. Chem. 248: 2645-2649.

10. Fox, R. H., and D. E. McClain. 1975. Enzyme electrophoretograms in the analysis of taxon relatedness of Micrococcus cryophilus, Branhamella catarrhalis and atypical neisserias. J. Gen. Microbiol. 86:210-216.

11. Fridovich, 1. 1975. Superoxide dismutases. Annu. Rev. Biochem. 44:147-159.

12. Jantzen, E., K. Bryn, T. Bergan, and K. Bøvre. 1974 Gas chromatography of bacterial whole cell methanolysates. V. Fatty acid composition of neisseriae and moraxellae. Acta Pathol. Microbiol. Scand. Sect. B 82: 767-779.

13. Jantzen, E., L. O. Frøholm, R. Hytta, and K. Bøvre. 1972. Gas chromatography of bacterial whole cell methanolysates. I. The usefulness of trimethylsilyl and trifluoroacetyl derivatives for strain and species charac terization. Acta Pathol. Microbiol. Scand. Sect. B 80: 660-671.

14. Keele, B. B., Jr., J. M. McCord, and I. Fridovich. 1970. Superoxide dismutase from Escherichia coli B. A new manganese-containing enzyme. J. Biol. Chem. 245: 6176-6181. 
15. Kirby, T., J. Blum, I. Kahane, and I. Fridovich. 1980 Distinguishing between Mn-containing and Fe-containing superoxide dismutases in crude extracts of cells. Arch. Biochem. Biophys. 201:551-555.

16. Lambert, M. A., D. G. Hollis, C. W. Moss, R. E. Weaver, and M. L. Thomas. 1971. Cellular fatty acids of nonpathogenic Neisseria. Can. J. Microbiol. 17: 1491-1502.

17. McCord, M. J., J. A. Boyle, E. D. Day, Jr., L. J. Rizzolo, and M. L. Salin. 1977. A manganese-containing superoxide dismutase from human liver, p. 129-138. In A. M. Michelson, J. M. McCord, and I. Fridovich (ed.), Superoxide and superoxide dismutases. Academic Press Inc., London.

18. McCord, J. M., and I. Fridovich. 1969. Superoxide dismutase. An enzymic function for erythrocuprein (hemocuprein). J. Biol. Chem. 244:6049-6055.

19. Morello, J. A., and M. Bohnhoff. 1980. Neisseria and Branhamella, p. 111-130. In E. H. Lennette, A. Balows, W. J. Hausler, Jr., and J. P. Truant (ed.), Manual of clinical microbiology, 3rd ed. American Society for Microbjology, Washington, D.C.

20. Morse, C. D., J. B. Brooks, and D. S. Kellogg, Jr. 1977. Identification of Neisseria by electron capture gas-liquid chromatography of metabolites in a chemically defined growth medium. J. Clin. Microbiol. 6:474481.

21. Morse, S. A., and L. Bartenstein. 1980. Purine metab- olism in Neisseria gonorrhoeae: the requirement for hypoxanthine. Can. J. Microbiol. 26:13-20.

22. Norrod, P., and S. A. Morse. 1979. Absence of superoxide dismutase in some strains of Neisseria gonorrhoeae. Biochem. Biophys. Res. Commun. 90:12871294.

23. Pile, J., and H. W. Dougherty. 1977. Ferrisuperoxide dismutase distribution in several bacteria. J. Gen. Appl. Microbiol. 23:303-310.

24. Puget, K., and A. M. Michelson. 1974. Isolation of a new copper-containing superoxide dismutase bacteriocuprein. Biochem. Biophys. Res. Commun. 58:830-838.

25. Reyn, A. 1974. Gram-negative cocci and coccobacilli, p. 427-433. In R. E. Buchanan and N. E. Gibbons (ed.), Bergey's manual of determinative bacteriology, 8 th ed. The Williams \& Wilkins Co., Baltimore.

26. Riou, J.-Y. 1977. Diagnostic bacteriologique des especes des genres Neisseria et Branhamella. Ann. Biol. Clin. 35: $73-87$.

27. Skerman, V. B. D., V. McGowan, and P. H. A. Sneath (ed.). 1980. Approved lists of bacterial names. Int. J. Syst. Bacteriol. 30:225-420.

28. Weisiger, R. A., and I. Fridovich. 1973. Superoxide dismutase. Organelle specificity. J. Biol. Chem. 248: 3582-3592.

29. Yost, F. J., and I. Fridovich. 1973. An iron-containing superoxide dismutase from Escherichia coli. J. Biol. Chem. 248:4905-4908. 